\title{
A Study on Membrane Filtration Characteristics of Methanogenic Mixed Liquor in Two Phase Anaerobic Digestion of Food Waste
}

\author{
Min-Ju Park ${ }^{1 \odot} \cdot$ Gyu-Tae Seo $^{2,+\odot}$ \\ 'Department of Environmental and Chemical Engineering, Eco-friendly Offshore Plant FEED Engineering Course, Changwon National \\ University \\ ${ }^{2}$ School of Civil, Environmental and Chemical Engineering, Changwon National University
}

(Received January 30, 2020; Revised March 2, 2020; Accepted March 3, 2020)

Objectives: An experimental study was conducted to investigate the membrane filtration characteristics of mixed liquor in methanogenic reactor to extend solid retention time (SRT) in food waste anaerobic digestion system.

Methods: On the basis of the particle size distribution $(0.5 \sim 700 \mu \mathrm{m})$ of the methanogenic mixed liquor, three grade membranes (MF, UF, NF) were tested in a stirred cell filtration and a plate type module. Furthermore foulants of membrane, especially UF, was investigated by SEM-EDS, FTIR, SEC.

Results and Discussion: As a result UF membrane was selected for stable filtration of the liquor in terms of flux $\left(2.51 \mathrm{~L} / \mathrm{m}^{2} \cdot \mathrm{h} \cdot\right.$ bar) and the flux recovery $(100 \%)$ as well as filtration resistance (Total 7.15.E+13 $\left.\mathrm{m}^{-1}\right)$. Average flux was $18 \mathrm{~L} / \mathrm{m}^{2} \cdot \mathrm{h} \cdot$ bar for the selected UF membrane in cross flow filtration using a flat plate module. The filtration results showed that membrane fouling was caused by gel and cake layer formed on the membrane surface and $90 \%$ of the initial flux could be recovered by physical washing. It was identified that major fouling causing materials were byproducts of carbohydrate and protein decomposition, and small amount of inorganic substance detected on the membrane surface were salt and struvite like materials.

Conclusions: Based on the membrane filtration characteristics analyzed from the study, the UF membrane coupled anaerobic digestion is feasible to be applied as a novel food waste treatment system for SRT extension of the methanogenic reactor.

Key Words: Anaerobic Digestion, Biogas, Food Waste, Solid Retention Time, Membrane Separation 


\title{
연구논문
}

\section{음식물쓰레기 2상 혐기성 소화 시스템 내 메탄 생성조 혼합액의 막 여과 특성}

\author{
박민주 $^{1 \odot} \cdot$ 서규태 $^{2,+\oplus}$
}

1창원대학교 친환경해양플랜트 FEED 공학과정 환경화공시스템공학전공

2창원대학교 토목환경화공융합공학부

목적: 본 연구에서는 2상 중온 혐기성 소화공정의 메탄 생성조 고형물체류시간(SRT)을 증가시켜 메탄 생산량 증 대를 위해 혼합액의 막 분리 특성을 실험적으로 조사하였다.

방법: 메탄 생성조 혼합액의 입경분포 $0.5 \sim 700 \mu \mathrm{m}$ 의 범위에 기반하여 3 등급의 막(MF, UF, NF)으로 Stirred cell 과 평판형 모듈을 이용해 혼합액의 여과실험을 수행하였다. 나아가 UF막의 막 오염 유발 물질은 SEM-EDS, FTIR, $\mathrm{SEC}$ 를 이용해 분석하였다.

결과 및 토의: 실험결과 UF 막이 투과 계수 $\left(2.51 \mathrm{~L} / \mathrm{m}^{2} \cdot \mathrm{h} \cdot \mathrm{bar}\right)$ 와 여과 후 표면세척에 따른 투과 계수의 회복률 $(100 \%)$ 및 막 여과 저항 $\left(T o t a l ~ 7.15 . \mathrm{E}+13 \mathrm{~m}^{-1}\right)$ 으로부터 가장 안정적인 여과가 가능한 것으로 나타났다. UF 막을 대 상으로 평판형 모듈을 이용한 십자류 흐름 여과실험에서 투과 계수가 평균 $18 \mathrm{~L} / \mathrm{m}^{2} \cdot \mathrm{h} \cdot \mathrm{bar}$ 로 유지되었고, 막 오염 은 주로 표면에 형성된 젤 및 케익층에 기인하였으나 물리적 세척으로 약 $90 \%$ 의 투과 유속이 회복되었다. 혼합액 의 여과에 따른 막 오염 유발 물질은 탄수화물과 단백질의 분해 산물 등의 유기 성분이 주를 이루었고 소량의 무 기 성분(염분, Struvite)으로 확인되었다.

결론: 이상의 막 여과 특성으로부터 UF 막 결합 2상 혐기성 소화 공정은 새로운 종류의 음식물쓰레기 처리 시스 템으로써 메탄 생성조의 고형물 체류 시간을 연장을 위한 적용가능성이 높은 것으로 판단된다.

주제어: 혐기성 소화, 바이오가스, 음식물쓰레기, 고형물 체류시간, 막분리

\section{1. 서론}

최근 기후변화에 대응하여 화석연료 사용량 저감을 위하 여 대체 에너지의 개발에 대한 관심이 높아지고 있다. 이에 혐기성 소화는 생분해 가능한 유기성 폐기물로부터 메탄과 같은 바이오 에너지를 생산함으로써 환경 및 위생적 측면 뿐 아니라 경제적으로도 상당히 유용한 공정으로 인식되고 있다. ${ }^{1)}$ Rodriguez-Iglesias 연구팀에 의하면 파일럿 규모 실 험에서 음식물쓰레기의 혐기성 소화에 의하여 메탄 함량 $66 \%$ 의 바이오가스를 생산할 수 있으며, ${ }^{2)}$ Sawayama 등은 유기성 폐기물의 처리를 Upflow anaerobic sludge blanket (UASB) 방식의 혐기성 소화 공정을 통한 에너지 회수가 도 시 고형폐기물의 소각을 통한 열에너지회수보다 우수함을 보여주었다. ${ }^{3)}$

혐기성 소화는 혐기성 미생물 작용으로 산생성(Acidogenesis and Acetogenesis) 및 메탄생성(Methanogenesis)의 2단계로 이
루어지며, 이와 같은 2 단계 반응이 단일 반응조 또는 2 개의 반응조로 나뉘어 각각 일어나는가에 따라 단상(Single phase) 및 2상(Two phase) 혐기성 소화 공정으로 구분한다. 단상 혐기 성 소화는 단순하면서 경제적이나 단일 반응조에서 2 단계의 반응이 공존함으로써 특히 메탄생성단계의 생물학적 반응의 최적화가 어렵다. 이에 반하여 2상 혐기성 소화는 2 개의 반응 조로 구분되어 다소 경제적인 면에서 부족하지만 산생성 단계 와 메탄생성 단계의 생물학적 반응을 최적화함으로써 메탄생 성 미생물 성장의 안정화에 의하여 바이오가스 중 메탄가스의 함량을 최대화할 수 있다. Shen et al.은 $2 \mathrm{~g} \mathrm{VS} / \mathrm{L} \cdot$ day 이상의 유기물 부하에서 단상 혐기성 소화 공정을 운전할 때 $\mathrm{pH}$ 가 낮아지는 반면 2상 혐기성 소화 공정은 $\mathrm{pH}$ 의 저하 없이 안정 적으로 운전되었으며 동시에 높은 메탄 수율과 유기물 처리용 량을 나타내었다. ${ }^{4)}$

혐기성 소화 공정의 운전에 미치는 영향 인자로서 $\mathrm{pH}$ 와 온도를 들 수 있다. 특히 온도는 고온 $\left(45-70^{\circ} \mathrm{C}\right)$ 및 중온(20 
$\left.-40^{\circ} \mathrm{C}\right)$ 으로 구분되는 혐기성 미생물그룹별 활성도뿐만 아 니라 기질의 용해도 및 대사속도에 미치는 영향도 크다. 그 러나 고온 혐기성 소화는 반응속도가 빠르나 온도에 민감 한 미생물의 활성을 유지하기 위하여 고도의 운전기술이 요구된다. 이에 비하여 중온 혐기성 소화는 미생물 반응이 환경변화에 민감하게 작용하지 않음으로 비교적 안정적인 운전이 가능하다. ${ }^{5)}$ 또한, 혐기성 소화 시스템의 설계 및 운 전에 미치는 중요한 인자는 체류시간과 유기물 부하(OLR: organic loading rate)로 알려져 있다. ${ }^{1)}$ 일반적으로 반응속도 가 낮은 혐기성 소화는 수리학적 체류시간(HRT: hydraulic retention time)과 고형물 체류시간(SRT: solid retention time) 을 동일하게 운전하므로 비교적 긴 HRT에 의한 소화조의 용량이 크게 요구된다. 게다가 고농도의 유기물을 처리하는 경우에는 OLR이 높아져 공정의 안정적인 운전이 어려워질 수 있다. ${ }^{6}$ Salminen 연구팀은 HRT를 조절하는 연구에서 가 금류 도축장 폐기물을 처리하는 중온 혐기성 소화조의 HRT 가 50 100일 일 때 공정이 안정적으로 운전되었으나, HRT 가 12 30일로 줄었을 때는 휘발성 유기산(VFAs: volatile fatty acids)의 축적과 메탄수율의 저하가 발생한 것으로 보 고하였다. ${ }^{7}$ 이에 따라 혐기성 소화 시스템의 설계 및 운전 의 최적화로 바이오가스 중 메탄 함량을 극대화함은 물론 시설의 경제성을 고려하여 소화조의 체류시간(HRT 또는 SRT)과 유기물 부하를 적정하게 유지해야 함을 알 수 있다. Nagao 연구팀에 의하면 단상 중온 혐기성 소화의 SRT를 60 일로 유지하고 HRT 16일에서 유기물 부하를 $9.2 \mathrm{~g} \mathrm{VS} / \mathrm{L}$ day까지 증가시켰을 때 메탄생성 수율이 $455 \mathrm{~mL} / \mathrm{g} \cdot$ day로 2 상 중온 혐기성 소화의 $360 \sim 373 \mathrm{~mL} / \mathrm{g}$ ·day보다 높게 나타 나 혐기성 소화 시스템에서 SRT를 HRT와 분리하여 높게 유 지함으로써 메탄생성량을 증가시킬 수 있음을 알 수 있다. ${ }^{8)}$

막 결합형 혐기성 소화(AnMBR: anaerobic membrane bioreactor)는 메탄생성조 미생물의 유실을 방지하여 SRT를 $\mathrm{HRT}$ 와 분리하여 조절할 수 있는 기술로써 짧은 HRT에서 도 고농도 유기물을 안정적으로 처리할 수 있다. ${ }^{9,10)}$ Apples 연구팀은 SRT가 길어질수록 바이오가스 생산량이 많아짐 을 보여주었으며, 실험실 규모의 배치 실험결과에서 체류시 간이 40 일 이상일 때 바이오가스 최대생산량인 $520 \mathrm{~mL} / \mathrm{g}$ 에 도달함을 보고했다. ${ }^{11)} \mathrm{Mei}$ 연구팀은 생활하수의 처리에 $\mathrm{AnMBR}$ 공정을 도입하여 생물 반응조의 HRT 최소 2.2 시간 에서 340 일간 $87 \%$ 의 $\mathrm{COD}$ (chemical oxygen demand) 제거 율을 유지하여 시스템을 안정적으로 유지할 수 있었다. ${ }^{12)}$ 한편 Amha 연구팀은 단상 AnMBR에 비해 2상 AnMBR 의 메탄 발생량이 $20.3 \%$ 높다는 점을 밝혔다. ${ }^{10)}$ 이러한 $\mathrm{AnMBR}$ 의 실적용을 위하여 막의 파울링과 용해된 메탄의 회수 그리고 알칼리도 등 여러 가지 해결해야 할 문제점이 있으며 이 중 막의 파울링이 비용과 에너지 소비의 측면에 서 가장 큰 문제점으로 부각되고 있다. ${ }^{13)}$
$\mathrm{AnMBR}$ 은 막 모듈이 메탄 생성조 내부에 위치하는 침지 형과 메탄 생성조 외부에 위치하는 순환형이 있다. Seib et al.은 순환형 막 모듈이 메탄 생성조 내 혼합액의 순환에 필 요한 에너지 때문에 운전비용이 높음을 지적했다. ${ }^{14)}$ 그러나 순환형은 침지형에 비해 고형물 함량이 높아 막 오염이 쉽 게 일어나는 폐수를 처리하는 경우 막 오염에 대한 저항과 투과 유속이 높으며 막 모듈과 분리막의 유지관리가 용이한 장점이 있다. ${ }^{15-17)}$

Kim은 일반적인 견해에 따른 Microfiltration (MF)과 Ultrafiltration (UF)의 비교 및 선정은 적합하지 않음을 지적 하고 있다. ${ }^{18)}$ 즉, 여과 대상 시료의 특성에 따라 투과 유속 및 처리 수의 수질이 우수한 막이 다를 수 있다. Castaing은 미세조류를 제거를 목적으로 $\mathrm{MF}$ 와 $\mathrm{UF}$ 를 비교한 결과 $\mathrm{MF}$ 가 우수한 투과 유속을 보였으며 주요 파울링 메커니즘은 케익층 형성에 의한 것임을 밝혔다. ${ }^{19)}$ Sun은 조류의 배양을 목적으로 $\mathrm{MF}$ 와 $\mathrm{UF}$ 를 비교하였으며, 같은 실험조건에서 두 막의 성능이 유사하게 나타났고 막 면 유속을 증가시켜 파 울링을 억제함으로써 투과 유속을 높게 유지할 수 있음을 보였다. ${ }^{20)}$ Dominguez는 동일한 유기물 부하율에서 MF와 $\mathrm{UF}$ 의 성능을 비교 분석하였을 때 $\mathrm{MF}$ 가 투과 유속의 안정 성 그리고 세척효율이 UF보다 높은 결과를 나타냈다. ${ }^{21)}$ Zulaikha는 음식점 폐수의 처리를 위해 UF와 Nanofiltration (NF)를 적용한 실험에서 $\mathrm{UF}$ 와 $\mathrm{NF}$ 의 $\mathrm{COD}$ 배제율은 유사하 였으나 UF의 Flux 회복률이 $15 \sim 38 \%$ 인 반면 NF의 Flux 회 복률은 $50 \%$ 이상인 점에서 $\mathrm{NF}$ 가 적합하다고 보고한 바 있 다. ${ }^{22)}$

본 연구에서는 3 가지 등급의 분리막(MF, UF, NF)을 사용 하여 2상 혐기성 소화 시스템의 메탄생성조 혼합액의 고액 분리에 적합한 막을 선정하고자 각 막의 투과 유속의 변화 를 실험적으로 조사하였다. 또한 막면유속과 물리적 세척에 의한 각 분리막의 여과 성능에 대한 영향을 관찰하였다. 마 지막으로 가장 적합한 것으로 나타난 분리막을 십자류 여과 방식의 모듈에 장착하여 단기 여과 성능을 관찰하고 파울링 물질을 분석하였다.

\section{2. 재료 및 방법}

\section{1. 실험장치 구성 및 운전}

\subsubsection{Stirred cell 여과}

여과 방식(전량여과와 십자류 흐름 여과)에 따른 세 등급 의 막(MF, UF, NF)에 대한 투과 유속(Flux) 변화와 회복률, 막 여과 저항을 비교하기 위해 Stirred cell (XFUF4701, Millipore)을 이용하였다. ${ }^{23)}$ 질소가스를 Cell의 상부에 공급 하여 여과압력을 조정 및 유지하였으며, Cell 내부에 마그네 틱 바가 장착되어있는 교반기로 교반 속도를 조절하여 막면 유속의 변화를 주었다. 투과수의 양을 1 분마다 기록하여 투 


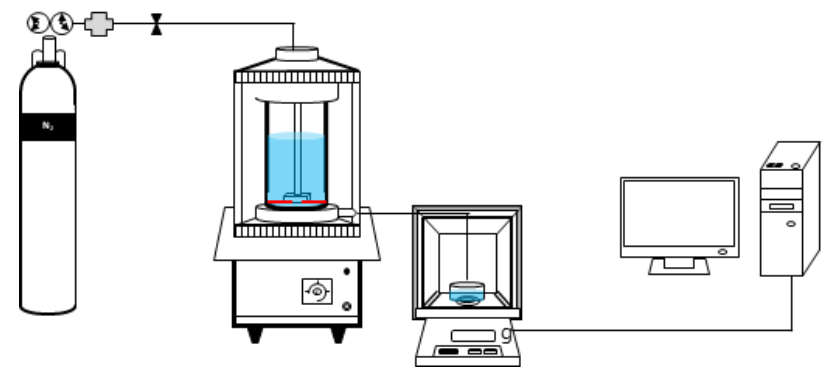

Fig. 1. Experimental apparatus of the membrane filtration using stirred cell.

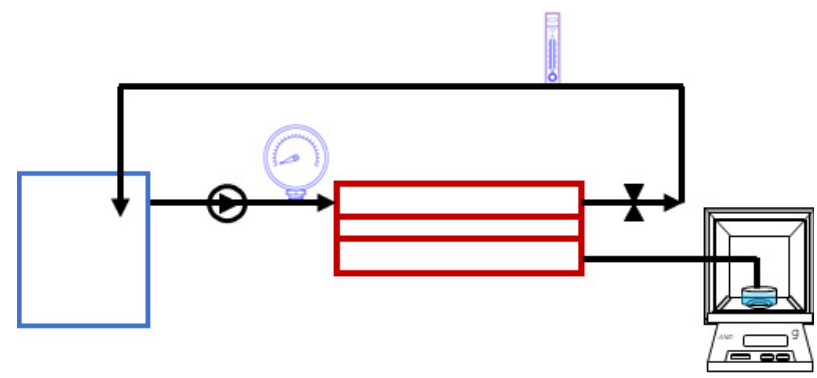

Fig. 2. Experimental apparatus for cross flow membrane filtration.

과 유속을 계산하였다. Fig. 1에 Stirred cell을 포함한 여과 장치의 구성을 나타내었다.

\subsection{2. 십자류 흐름(Cross flow) 여과}

Stirred cell에서는 막 표면에 회전력을 주어 십자류 여과 방식을 모사하였기 때문에 실제 십자류 여과 방식의 결과와 다를 수 있다. ${ }^{24)}$ 따라서 실제로 십자류 흐름 여과 방식을 적 용할 수 있도록 Fig. 2와 같이 제작된 평판형 모듈을 사용하 여 Table 2의 조건에서 여과했을 때의 투과 유속 감소와 회 복률을 관찰하였다.

\section{2. 실험 재료}

\subsection{1. 여과 대상 시료}

음식물쓰레기를 처리하는 파일럿 규모 $(5 \mathrm{~kg} / \mathrm{day}) 2$ 상 중 온 혐기성 소화 공정의 메탄생성조 내 혼합액을 여과대상
시료로 사용하였다. 혐기성 소화 공정의 유입 음식물쓰레기 는 입경 $2 \mathrm{~mm}$ 이하로 분쇄하여 수돗물과 $1: 1$ 의 비율로 혼합 하였으며 유기물 부하율은 $3 \mathrm{~g} \mathrm{VS} / \mathrm{L} \cdot$ day이다. 막의 손상을 최소화하고 실험장치의 막힘을 방지하기 위해 대상 시료를 $600 \mu \mathrm{m}$ 의 체로 거른 뒤 막 여과를 수행하였다.

\subsection{2. 분리막}

Stirred cell 여과 실험에 사용된 막의 등급별로 재질과 공 극의 크기, 실험조건을 Table 1에 나타내었다. MF와 $\mathrm{UF}$ 의 여과압력은 $1 \mathrm{bar}$ 로 설정하였으며 공극이 상대적으로 작은 $\mathrm{NF}$ 의 여과 압력은 일반적으로 $\mathrm{MF}$ 및 UF보다 높게 설정되 며 본 연구에서 사용된 Stirred cell의 가압 한계치에 따라 5 bar로 설정하였다. 여과 종료 후 막 표면을 스펀지로 가볍게 문지르고 증류수로 헹궈내어 물리적 세척을 수행하였으며 다음 실험에 사용되기 전까지 $10 \%$ 의 에탄올에 넣어 $4{ }^{\circ} \mathrm{C}$ 에 서 보관하였다.

\section{3. 분석방법}

\subsection{1. 대상 시료의 성상 분석}

대상 시료의 성상을 particle size distribution (PSD), $\mathrm{pH}$, total chemical oxygen demand (TCOD), soluble chemical oxygen demand (SCOD), suspended solid (SS), total solid (TS), volatile solid (VS), VFAs 그리고 extracellular polymeric substances (EPS) 항목으로 분석하였다. 원심분리로 배제할 수 있는 입 자의 크기를 관찰하기 위해 소화 슬러지 원수와 상등수 (5000 rpm, $30 \mathrm{~min}$ )의 $\mathrm{PSD}$ 를 각각 측정하였다. 입도분석기 (Mastersizer2000, Malvern Korea)는 Mie Theory를 적용한 Laser diffraction방법을 기반으로 하고 있으며 측정 범위는 0.02 2000 $\mu \mathrm{m}$ 이다. $\mathrm{pH}$ 는 $\mathrm{pH}$ 미터기(Seven compact $\mathrm{pH} / \mathrm{ION}$, Mettler Toledo)를 사용하였으며 TCOD와 SCOD는 CODcr법 에 기초한 분석용 키트 $(2125925, \mathrm{Hach})$ 를 이용해 분석하였다. $\mathrm{SCOD}$ 와 VFAs 측정은 샘플을 $5,000 \mathrm{rpm}$ 에서 30 분간 원심분 리한 후 상등액을 $0.45 \mu \mathrm{m}$ 시린지 필터로 여과한 뒤 수행하였 다. VFAs는 고성능 액체크로마토그래피(LC-20A, Shimadzu) 를 이용하여 분석하였으며, 검출기는 UV detector로 $210 \mathrm{~nm}$ 의

Table 1. Specification of the membranes and filtration condition.

\begin{tabular}{|c|c|c|c|}
\hline Items & $\begin{array}{l}\text { Microfiltration } \\
\text { (MF) }\end{array}$ & $\begin{array}{c}\text { Ultrafiltration } \\
\text { (UF) }\end{array}$ & $\begin{array}{c}\text { Nanofiltration } \\
\text { (NF) }\end{array}$ \\
\hline Pore size & $\varnothing 7 \mu \mathrm{m}$ & MWCO 100 kDa & MWCO $350 \mathrm{Da}$ \\
\hline Material & Glass Microfiber & Polyethersulfone & $\begin{array}{c}\text { Polyamide TFC } \\
\text { on Polyethersulfone }\end{array}$ \\
\hline $\begin{array}{l}\text { Applied pressure } \\
\text { (bar) }\end{array}$ & & & 5 \\
\hline $\begin{array}{l}\text { Filtration time } \\
(\min \times \text { cycle })\end{array}$ & & $60 \times 3$ & \\
\hline Cleaning method & & Physical cleaning & \\
\hline
\end{tabular}


Table 2. UF membranes properties for cross flow filtration.

\begin{tabular}{|c|c|c|}
\hline & Contents & Ultrafiltration membrane \\
\hline \multirow{3}{*}{ Properties } & Material & Polyethersulfone \\
\hline & $\begin{array}{l}\text { MWCO } \\
(\mathrm{kDa})\end{array}$ & 100 \\
\hline & $\begin{array}{l}\text { Filtration area } \\
\qquad\left(\mathrm{cm}^{2}\right)\end{array}$ & 72 \\
\hline \multirow{4}{*}{ Conditions } & $\begin{array}{l}\text { Cross flow velocity } \\
(\mathrm{m} / \mathrm{s})\end{array}$ & 0.24 \\
\hline & $\begin{array}{c}\text { Pressure } \\
\text { (bar) }\end{array}$ & 1 \\
\hline & $\begin{array}{l}\text { Filtration time } \\
(\mathrm{h} \times \text { cycle })\end{array}$ & $4 \times 3$ \\
\hline & Cleaning method & Physical cleaning \\
\hline
\end{tabular}

파장에서 측정하였다. 분석에 사용된 컬럼은 Bio-Rad사의 300 $\times 7.8 \mathrm{~mm}$ Aminex HPX-87H이다. 이동상으로 $0.005 \mathrm{M}$ 황산용 액을 사용하였으며 유속은 $0.6 \mathrm{~mL} / \mathrm{min}$ 으로 설정하였다. TS, VS 항목은 수질오염공정시험기준에 따라 분석하였다. ${ }^{25)} \mathrm{EPS}$ 는 열 처리법을 통해 추출하고 VS 항목과 동일한 방법으로 분석하였 으며, ${ }^{26)}$ 추출된 EPS의 탄수화물과 단백질의 함량은 각각 Phenol-sulfuric acid법과 Lowry법을 이용해 측정하였다. ${ }^{27,28)}$ 분 석에 사용된 증류수는 저항 $18.2 \Omega$ 이상이었으며 초순수 제조 기(AQUAX-MAX-311, YL instruments)를 사용하여 제조하였 다. 각 항목은 3 회 분석한 결과의 평균값으로 나타내었다.

\subsection{2. 투과 유속과 회복률}

전자저울을 컴퓨터와 연결하여 투과수의 양을 1 분 간격으 로 측정하였다. 식 (1)에 따라 투과수의 양, 막 면적과 여과 시간을 고려하여 투과 유속(J)으로 표현하였다. 여과 전과 후 의 투과 유속을 식 (2)에 대입하여 투과 유속 회복률(r)을 고 려하였다.

여기서 $\mathrm{Q}$ 는 투과수 양 $(\mathrm{L}), \mathrm{A}$ 는 막면적 $\left(\mathrm{m}^{2}\right), \Delta \mathrm{t}$ 는 측정간 격(h), $\mathrm{J}_{\mathrm{p}}$ 와 $\mathrm{J}_{\mathrm{r}}$ 은 각각 새 막과 여과 후 물리적으로 세척된 막 의 증류수 투과 유속 $\left(\mathrm{L} / \mathrm{m}^{2} \cdot \mathrm{h}\right)$ 를 의미한다.

$$
\begin{gathered}
J=\frac{Q}{A \triangle t} \\
r=\frac{J_{r}}{J_{p}}
\end{gathered}
$$

\subsection{3. 막 여과 저항}

세 가지 막의 여과 저항을 Darcy's law 식에서 변형된 식 (3)과 (4)를 이용해 계산하였다. 여기서 $\Delta \mathrm{P}$ 는 막간 차압( $\mathrm{kPa})$, $\mu$ 는 투과수의 점도 $(\mathrm{Pa} \cdot \mathrm{s}), \mathrm{R}_{\mathrm{m}}, \mathrm{R}_{\mathrm{p}}, \mathrm{R}_{\mathrm{c}}, \mathrm{R}_{\mathrm{t}}$ 는 각각 막 고유의 여과 저항, 공극 막힘에 의한 저항, 케익층 형성에 의한 저항, 총 여과저항을 의미한다. ${ }^{29}$

$$
\begin{gathered}
J=\frac{\triangle P}{\mu R} \\
R_{t}=R_{m}+R_{p}+R_{c}
\end{gathered}
$$

막 여과 저항은 1) 새 분리막으로 초순수를 여과할 때의 투과 유속 측정 $\left.\left(\mathrm{R}_{\mathrm{m}}\right), 2\right)$ 메탄 생성조 혼합액을 여과할 때의 투과 유속 측정 $\left.\left(\mathrm{R}_{\mathrm{t}}\right), 3\right)$ 막 표면의 케익층을 제거한 후 초순 수를 여과할 때의 투과유속 측정 $\left.\left(\mathrm{R}_{\mathrm{p}}\right), 4\right)$ 식 (4)를 활용하여 $\mathrm{R}_{\mathrm{c}}$ 를 계산하는 순서로 측정하였다.

\subsection{4. 막오염 물질 분석}

2.3.4.1. Scanning electron microscopy - Energy dispersive spectroscopy (SEM-EDS)

여과 전과 후의 막 표면을 관찰하기 위해 전계방사형 주 사전자 현미경(CZ/MIRA I LMH, ZEISS)을 이용하여 가속 전압 $20 \mathrm{kv}$ 에서 촬영하였다. 샘플은 실리카 겔이 충진된 데 시게이터내에서 건조하여 실온에서 보관하였다가 측정 전 에 Sputter coater (SC7640, Polaron)를 사용하여 막 표면을 백금으로 코팅하였다. 또한, 막오염에 관여하는 무기원소를

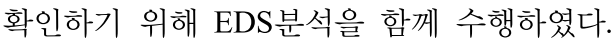

2.3.4.2. Fourier transform infrared spectroscopy (FTIR) 막오염에 관여하는 유·무기 물질을 확인하기 위해 막 표면의 작용기 및 원소 결합형태를 FTIR spectrometer (FT/IR-6300, $\mathrm{JASCO}$ )를 이용하여 파장 범위 $600 \sim 4000 \mathrm{~cm}^{-1}$ 에서 분석하였다.

\subsubsection{Size exclusion chromatography (SEC)}

유입 혼합액과 투과수, 농축수를 대상으로 물질의 분 자량을 측정하기 위해 $\mathrm{SEC}$ 를 수행하였다. 분석 장비는 HPLC-SEC으로 Protein Pak $125 \AA$ (Waters) 컬럼을 사용하 였으며 이동상으로 $0.01 \mathrm{M} \mathrm{NaCl}$ 을 $0.5 \mathrm{~mL} / \mathrm{min}$ 으로 흘려주 었다. 검출기는 UV $(254 \mathrm{~nm})$ 이며 검량선 작성을 위한 표준 물질은 Polystyrene sulfonate이며 분자량 $18,8,4.6,1 \mathrm{kDa}$ 를 사용하였다.

\section{3. 결과 및 고찰}

\subsection{2상 혐기성 소화 메탄생성조 혼합액}

2상 중온 혐기성 소화 공정의 혼합액 특성을 파악하기 위 해 메탄생성조 내 혼합액의 $\mathrm{pH}, \mathrm{TCOD}, \mathrm{SCOD}, \mathrm{SS}, \mathrm{TS}, \mathrm{VS}$ 및 VFAs의 농도를 분석하였다. 혼합액의 $\mathrm{pH}$ 는 7.6 \pm 0.1 으로 메탄생성에 최적 범위인 7 8을 유지하였다. ${ }^{30)} \mathrm{SS}$ 와 TS, VS 는 각각 $25.5 \pm 2.35 \mathrm{~g} / \mathrm{L}, 29.4 \pm 1.59 \mathrm{~g} / \mathrm{L}, 11.6 \pm 0.658 \mathrm{~g} / \mathrm{L}$ 로 고 농도의 고형물을 함유하고 있으며 $\mathrm{TCOD}$ 와 $\mathrm{SCOD}$ 는 각 각 $19 \pm 1.2 \mathrm{~g} / \mathrm{L}, 4.4 \pm 1.5 \mathrm{~g} / \mathrm{L}$ 였다. VFAs로써 Acetic acid와 Propionic acid는 각각 $920 \pm 440 \mathrm{mg} / \mathrm{L}, 112 \pm 70 \mathrm{mg} / \mathrm{L}$ 로 나타 
Table 3. The characteristics of mixed liquor in methanogenic reactor.

\begin{tabular}{ccc} 
Characteristics & Unit & Mixed liquor \\
TCOD & $\mathrm{g} / \mathrm{L}$ & $19 \pm 1.2$ \\
SCOD & $\mathrm{g} / \mathrm{L}$ & $4.4 \pm 1.5$ \\
$\mathrm{SS}$ & $\mathrm{g} / \mathrm{L}$ & $25.5 \pm 2.35$ \\
TS & $\mathrm{g} / \mathrm{L}$ & $29.4 \pm 1.59$ \\
$\mathrm{VS}$ & $\mathrm{g} / \mathrm{L}$ & $11.6 \pm 0.658$ \\
$\mathrm{pH}$ & - & $7.6 \pm 0.1$ \\
Lactic & $\mathrm{mg} / \mathrm{L}$ & - \\
Acetic & $\mathrm{mg} / \mathrm{L}$ & $920 \pm 440$ \\
Propionic & $\mathrm{mg} / \mathrm{L}$ & $112 \pm 70$ \\
Butyric & $\mathrm{mg} / \mathrm{L}$ & - \\
\hline
\end{tabular}

났고 Lactic acid와 Butyric acid는 검출되지 않았다. 이는 혐기 성 소화 연구에서 메탄생성조의 $\mathrm{pH}$ 가 6 7인 경우 Butyric $\mathrm{acid}$ 가 높게 나타나지만 $\mathrm{pH}$ 가 8에 가까운 경우 Acetic acid와 Propionic acid가 높은 농도로 나타난 결과와 유사하다. ${ }^{31)}$ 상 기 혐기성 소화 액의 수질 분석 결과를 Table 3에 나타내었다. 원심분리기를 이용하여 회수할 수 있는 입자의 범위를 관 찰하기 위해 메탄생성조 혼합액과 이를 원심분리한 이후 상 등액을 대상으로 입도분석기(Mastersizer 2000, Malvern Korea)를 이용하여 $0.02 \sim 2000 \mu \mathrm{m}$ 범위에서 입도분포를 분 석하였고 그 결과를 Fig. 3에 나타내었다. 입도분석을 위해 분석 시료는 초음파를 이용하여 입자를 분리하는 전처리를 수행하였다. 메탄생성조 혼합액과 원심분리 이후 상등액에 서 동일하게 $0.5 \mu \mathrm{m}$ 부터 $700 \mu \mathrm{m}$ 범위의 입자가 관찰되었 다. 원수와 상등액의 입도 분포 경향은 약 $20 \mu \mathrm{m}$ 까지 비슷 했으며 그 이상에서 분포비율의 차이가 관찰되었다. 특히 $200 \sim 700 \mu \mathrm{m}$ 범위의 입자가 주로 제거되어 분포비율의 차 이가 명확하게 나타났다. 그러나 메탄생성에 관여하는 미생 물의 크기는 $0.3 \sim 7.4 \mu \mathrm{m}$ 이므로, ${ }^{32)}$ 원심분리를 통해 SRT를 조절하는 것은 보다 세밀한 검토가 필요하다.

\section{2. 메탄생성조 혼합액의 막 여과 특성}

메탄생성조 혼합액의 입도 분석 결과를 바탕으로 혼합액 의 분리막에 의한 고액분리 특성을 검토하기 위하여 막의 등급(MF, UF, NF)에 따른 막 여과 특성을 조사하였다.

\subsection{1. 투과 유속과 막 여과 저항}

등급별(MF, UF, NF) 분리막을 이용하여 Stirred cell에 의 한 혼합액의 막 여과 실험을 진행하였다. 여과 방식은 전량 여과(Dead end filtration)로 여과 압력을 MF와 UF는 $1 \mathrm{bar}$ 로, $\mathrm{NF}$ 는 $5 \mathrm{bar}$ 로 설정하였다. 여과 실험은 1 회당 60 분씩 총 3 회 실시하였다. 1 회 여과 종료 후 막 표면을 스펀지로 부드럽게 문지른 뒤 증류수로 씻어내는 물리적 세척을 하였 다. Fig. 4는 분리막 등급별 투과 유속과 물리적 세척에 의

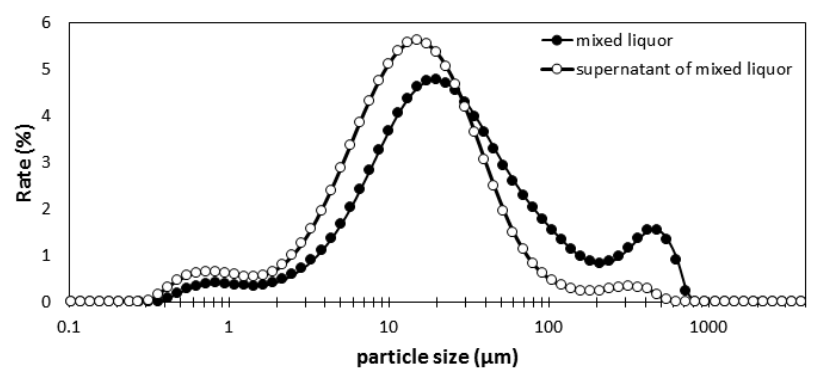

Fig. 3. Particle size distribution of anaerobic mixed liquor and supernatant after centrifugation.

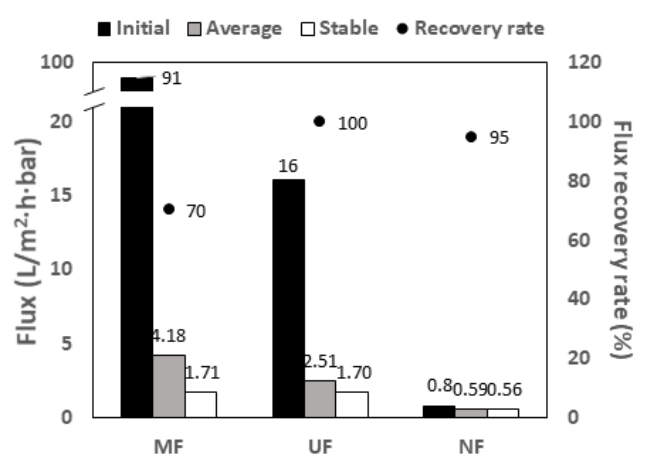

Fig. 4. Comparison of flux and recovery rate for membrane filtration of the methanogenic mixed liquor.

한 투과 유속 회복률을 나타낸 것이다.

$\mathrm{MF}$ 막의 1 회차 실험에서 초기 투과 유속은 $91 \mathrm{~L} / \mathrm{m}^{2} \cdot \mathrm{h} \cdot \mathrm{bar}$ 였으나 1 분만에 $11 \mathrm{~L} / \mathrm{m}^{2} \cdot \mathrm{h} \cdot \mathrm{bar}$ 로 급격히 감소하여 30 분 이 후 $1.71 \mathrm{~L} / \mathrm{m}^{2} \cdot \mathrm{h} \cdot \mathrm{bar}$ 를 유지하였다. 평균 투과 유속은 4.18 $\mathrm{L} / \mathrm{m}^{2} \cdot \mathrm{h} \cdot \mathrm{bar}$ 이었다. 물리적 세척 이후 평균 투과 유속은 $2.94 \mathrm{~L} / \mathrm{m}^{2} \cdot \mathrm{h} \cdot \mathrm{bar}$ 로 $70 \%$ 가 회복되었다. 2 회차와 3 회차의 초기 투과 유속은 각각 30 과 $28 \mathrm{~L} / \mathrm{m}^{2} \cdot \mathrm{h} \cdot \mathrm{bar}$ 로 1 회차에 비해 급감하였다. 여과시작 30 분 이후의 유지 투과 유속은 2 회, 3 회차의 경우 $1.68,1.71 \mathrm{~L} / \mathrm{m}^{2} \cdot \mathrm{h} \cdot \mathrm{bar}$ 로 1 차 여과실험과 유 사한 값을 기록했다. 물리적 세척 이후에 $\mathrm{MF}$ 의 평균 투과 유속이 $30 \%$ 감소한 것은 Fig. 3 의 $\mathrm{SEC}$ 분석 결과 $\mathrm{MF}$ 막 의 공극 $7 \mu \mathrm{m}$ 영역대의 입자로부터 Intermediate blocking 및 Complete blocking과 같은 현상에 의해 막의 공극이 막힘에 기인함을 알 수 있다.

$\mathrm{UF}$ 막의 경우, 1 회차의 초기 투과 유속은 $16 \mathrm{~L} / \mathrm{m}^{2} \cdot \mathrm{h} \cdot \mathrm{bar}$ 였으며 1 분 만에 $8 \mathrm{~L} / \mathrm{m}^{2} \cdot \mathrm{h} \cdot \mathrm{bar}$ 로 감소하였으며 평균 투과 유속은 $2.51 \mathrm{~L} / \mathrm{m}^{2} \cdot \mathrm{h} \cdot \mathrm{bar}$ 로 나타났다. 물리적 세척 이후 평 균 투과 유속은 $2.62 \mathrm{~L} / \mathrm{m}^{2} \cdot \mathrm{h} \cdot \mathrm{bar}$ 로 $100 \%$ 회복되었으며 2 회 차와 3회차의 초기 투과 유속도 16 과 $17 \mathrm{~L} / \mathrm{m}^{2} \cdot \mathrm{h} \cdot \mathrm{bar}$ 로 나타 나 $100 \%$ 회복되었다. 또한, $1,2,3$ 회차의 유지 투과 유속은 각각 $1.7,1.8,1.8 \mathrm{~L} / \mathrm{m}^{2} \cdot \mathrm{h} \cdot \mathrm{bar}$ 로 유사하게 나타났다. 모든 회차의 초기 투과 유속이 유사한 것으로 보아 물리적 세척 에 의해 투과 유속이 완전히 회복되었으며 이는 막 표면에 발생한 가역적 케익 및 젤층 형성이 투과 유속 감소의 주된 
Table 4. The value of filtration resistances on each type of membrane.

\begin{tabular}{cccc} 
Items & MF & UF & $N F$ \\
$R_{m}$ & $5.93 . E+10$ & $2.82 . E+11$ & $5.34 . E+13$ \\
$R_{p}$ & $3.57 . E+12$ & $1.43 . E+11$ & $5.55 . E+11$ \\
$R_{c}$ & $6.46 . E+13$ & $7.10 . E+13$ & $3.24 . E+14$ \\
$R_{t}$ & $6.81 . E+13$ & $7.15 . E+13$ & $3.78 . E+14$ \\
\hline
\end{tabular}

파울링 현상임을 알 수 있다. ${ }^{33)}$

$\mathrm{NF}$ 의 초기 투과 유속은 $1,2,3$ 회차에서 각각 $0.80,0.68$, $0.60 \mathrm{~L} / \mathrm{m}^{2} \cdot \mathrm{h} \cdot \mathrm{bar}$ 이었으며 평균 투과 유속은 $0.59,0.56,0.55$ $\mathrm{L} / \mathrm{m}^{2} \cdot \mathrm{h} \cdot \mathrm{bar}$, 유지 투과 유속은 $0.56,0.53,0.46 \mathrm{~L} / \mathrm{m}^{2} \cdot \mathrm{h} \cdot \mathrm{bar}$ 로 나타나 파울링에 의한 초기 및 유지 투과 유속 차이가 가장 작은 것으로 나타났다. 그러나 $\mathrm{NF}$ 는 여과 압력이 5 bar로 높음에도 불구하고 분획분자량이 $350 \mathrm{Da}$ 으로 공극이 아주 작기 때문에 초기 및 유지 투과 유속 값이 MF와 UF에 비해 $1 / 3$ 수준으로 나타났다.

$\mathrm{MF}, \mathrm{UF}, \mathrm{NF}$ 에서 1 회차의 초기 투과 유속은 $91,16,0.8$ $\mathrm{L} / \mathrm{m}^{2} \cdot \mathrm{h} \cdot \mathrm{bar}$ 로 공극의 크기에 비례하여 높게 나타났으나 평 균 투과 유속은 초기 투과 유속과 대비하여 $95,84,30 \%$ 감 소하였으며, 공극의 크기가 클수록 파울링에 의한 초기 투 과 유속 감소가 심각하게 발생했다. 물리적 세척에 의한 $\mathrm{MF}, \mathrm{UF}, \mathrm{NF}$ 의 평균 투과 유속 회복률은 $70,100,95 \%$ 로 $\mathrm{MF}$ 가 가장 낮게 나타나 물리적으로 세척이 어려운 비가역 적 파울링이 심하게 일어났다. 초기 투과 유속 감소율과 회 복률을 고려했을 때 NF가 가장 우수하지만, 운전 압력이 상 대적으로 높고 투과 유속 값이 낮게 나타나 실제 막 여과 공정에 적용하기에 경제적인 측면에서 부적합한 것으로 사 료된다. 따라서 UF가 투과 유속의 감소 및 회복과 처리용량 측면에서 가장 효율적인 운전 및 유지가 가능할 것으로 판 단된다.

막 여과 실험을 통해 얻은 세 막의 여과특성 비교 결과를 검토하기 위해 막 여과 저항을 측정하였다. 막 여과 저항 $\mathrm{R}_{\mathrm{t}}$ 는 식 (4)로 표현된다. ${ }^{29)}$

$$
R_{t}=R_{m}+R_{p}+R_{c}
$$

$\mathrm{MF}, \mathrm{UF}, \mathrm{NF}$ 의 막 여과 저항값을 Table 4에 나타내고 $\mathrm{R}_{\mathrm{t}}$ 에 대한 $\mathrm{R}_{\mathrm{m}}, \mathrm{R}_{\mathrm{p}}, \mathrm{R}_{\mathrm{c}}$ 의 비율을 Fig.5에 나타내었다. 막의 공 극 및 특성에 따라 결정되는 $\mathrm{R}_{\mathrm{m}}$ 은 $\mathrm{MF}, \mathrm{UF}, \mathrm{NF}$ 가 각각 $5.93 \mathrm{E}+10,2.82 \mathrm{E}+11,5.34 \mathrm{E}+13 \mathrm{~m}^{-1}$ 로 공극이 작을수록 크게 나타났다. 여과 대상 시료의 특성에 따라 달라지는 $\mathrm{R}_{\mathrm{p}}$ 는 $\mathrm{MF}, \mathrm{UF}, \mathrm{NF}$ 가 각각 $3.57 \mathrm{E}+12,1.43 \mathrm{E}+11,5.55 \mathrm{E}+11 \mathrm{~m}^{-1}$ 로 $\mathrm{MF}$ 가 가장 높게 나타났다. 케익 및 젤층에 의한 여과 저항 $\mathrm{R}_{\mathrm{c}}$ 는 각각 $6.46 \mathrm{E}+13,7.10 \mathrm{E}+13,3.24 \mathrm{E}+14 \mathrm{~m}^{-1}$ 로 $\mathrm{MF}$ 와 $\mathrm{UF}$ 는 유사했으며 운전 압력이 $5 \mathrm{bar}$ 인 NF가 가장 낮게 나타났 다. $\mathrm{MF}$ 의 총 여과 저항 $\mathrm{R}_{\mathrm{t}}$ 중 $\mathrm{R}_{\mathrm{m}}, \mathrm{R}_{\mathrm{p}}, \mathrm{R}_{\mathrm{c}}$ 가 차지하는 비율은

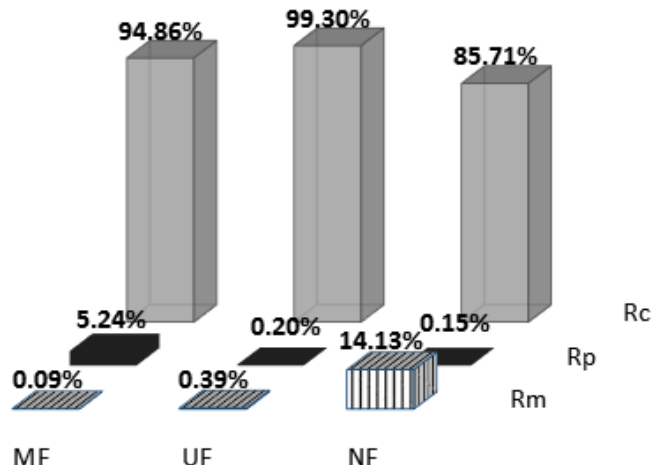

Fig. 5. The ratio of filtration resistances on each type of membrane.

각각 $0.09,5.23,94.68 \%$ 로 $\mathrm{R}_{\mathrm{c}}$ 가 가장 높았으며 UF 및 $\mathrm{NF}$ 와 비교했을 때 상대적으로 $\mathrm{R}_{\mathrm{p}}$ 가 높게 나타났다. UF에서는 $\mathrm{R}_{\mathrm{m}}, \mathrm{R}_{\mathrm{p}}, \mathrm{R}_{\mathrm{c}}$ 가 $0.39,0.20,99.30 \%$ 를 차지하며 $\mathrm{R}_{\mathrm{c}}$ 가 월등히 높 았고 $\mathrm{R}_{\mathrm{m}}$ 이 $\mathrm{R}_{\mathrm{p}}$ 보다 조금 더 높은 비율을 차지했다. $\mathrm{NF}$ 의 경 우 $\mathrm{R}_{\mathrm{m}}, \mathrm{R}_{\mathrm{p}}, \mathrm{R}_{\mathrm{c}}$ 가 $14.13,0.15,85.72 \%$ 로 나타나 $\mathrm{R}_{\mathrm{c}}$ 가 우세했 으나 다른 막에 비해 $\mathrm{R}_{\mathrm{m}}$ 이 높은 비율로 나타났다. 고농도 고형물을 함유하는 혐기 소화 슬러지로 인해 모든 막에서 막면 케익 및 젤층 형성에 의한 여과 저항 $\mathrm{R}_{\mathrm{c}}$ 가 가장 높게 나타났으나, $\mathrm{MF}$ 는 공극 막힘에 의한 여과 저항이 상대적으 로 높게 나타나 쉽게 제거되지 않는 비가역적 파울링이 많 이 일어날 것으로 예상된다. 이는 3회 여과 실험에서 물리 적 세척에 의한 $\mathrm{MF}$ 의 투과 유속 회복률이 가장 낮은 원인 으로 볼 수 있다. $\mathrm{UF}$ 와 $\mathrm{NF}$ 의 $\mathrm{R}_{\mathrm{p}}$ 는 낮게 나타나 물리적 세 척에 의한 플럭스 회복에 유리하다. 하지만 NF는 막 자체에 의한 여과 저항 $\mathrm{R}_{\mathrm{m}}$ 이 비교적 높게 나타나 투과 유속값이 현 저히 낮으므로 혐기 소화의 SRT조절에는 UF의 적용가능성 이 가장 높은 것으로 판단된다.

\subsection{2. 물질 배제 특성}

메탄생성조 유입수와 막의 투과수 $\left(\mathrm{MF}_{\mathrm{p}}, \mathrm{UF}_{\mathrm{p}}, \mathrm{NF}_{\mathrm{p}}\right)$ 의 $\mathrm{COD}$, $\mathrm{TS}, \mathrm{VS}, \mathrm{FS}$ 그리고 염도를 Table 5에 나타내었다.

유입수(feed solution)의 TCOD는 $21 \mathrm{~g} / \mathrm{L}$ 였으며 막의 투과 수는 각각 MF $6.2 \mathrm{~g} / \mathrm{L}, \mathrm{UF} 5.5 \mathrm{~g} / \mathrm{L}, \mathrm{NF} 3.1 \mathrm{~g} / \mathrm{L}$ 로 배제율은 $71 \%, 74 \%, 85 \%{ }^{34)}$ 로 나타났다. 유입수 TS는 $28.2 \mathrm{~g} / \mathrm{L}$ 로 $\mathrm{VS}$ 가 $15.4 \mathrm{~g} / \mathrm{L}$ 이고 $\mathrm{FS}$ 는 $12.6 \mathrm{~g} / \mathrm{L}$ 였다. 이에 대하여 $\mathrm{MF}_{\mathrm{p}}, \mathrm{UF}_{\mathrm{p}}$, $\mathrm{NF}_{\mathrm{p}}$ 의 $\mathrm{TS}$ 는 각각 $17.9 \mathrm{~g} / \mathrm{L}, 16.6 \mathrm{~g} / \mathrm{L}, 12.3 \mathrm{~g} / \mathrm{L}$ 로 감소했다. $\mathrm{VS}$ 는 $6.06 \mathrm{~g} / \mathrm{L}, 5.86 \mathrm{~g} / \mathrm{L}, 4.06 \mathrm{~g} / \mathrm{L}$ 로 $60 \%, 62 \%, 73 \%$ 의 배 제율을 보였다. 한편 막 투과수의 FS는 각각 $11.9 \mathrm{~g} / \mathrm{L}, 10.7$ $\mathrm{g} / \mathrm{L}, 8.22 \mathrm{~g} / \mathrm{L}$ 로 배제율 $4 \%, 15 \%, 35 \%$ 을 나타내었다. 이로 부터 막 투과수 내 고형물의 배제는 대부분 VS에서 일어났 음을 알 수 있다. 메탄생성조 내 유입수의 VS의 농도가 높 을수록 메탄생성 수율도 함께 높아질 수 있으므로 분리막에 의한 VS의 높은 배제율은 바이오가스와 메탄 생성량의 증 대에 기여할 것으로 추정할 수 있다. ${ }^{35)} \mathrm{FS}$ 는 대부분 투과되 
Table 5. The characteristics of feed and permeate of MF, UF and NF.

\begin{tabular}{|c|c|c|c|c|c|c|}
\hline & & $\begin{array}{c}\text { TCOD } \\
(g / L)\end{array}$ & $\begin{array}{c}\text { TS } \\
(\mathrm{g} / \mathrm{L})\end{array}$ & $\begin{array}{l}\text { VS } \\
\text { (g/L) }\end{array}$ & $\begin{array}{c}\text { FS } \\
\text { (g/L) }\end{array}$ & $\begin{array}{c}\text { Salinity } \\
(\%)\end{array}$ \\
\hline \multirow[t]{2}{*}{ Feed } & & 21 & 28.2 & 15.4 & 12.6 & 1.04 \\
\hline & MF & 6.1 & 17.9 & 6.06 & 11.9 & 1.06 \\
\hline \multirow[t]{2}{*}{ Permeate } & UF & 5.5 & 16.6 & 5.86 & 10.7 & 1.08 \\
\hline & NF & 3.1 & 12.3 & 4.06 & 8.22 & 0.96 \\
\hline
\end{tabular}

었으나 막의 공극이 작은 분리막에서 배제율이 상승하였다. $\mathrm{FS}$ 는 무기성 물질을 포함하는 용존성 물질로 메탄 생성에 기여하지 못한다. ${ }^{36)}$ 주재영 연구팀의 연구 결과에 의하면 $\mathrm{FS}$ 의 농도가 증가할 때 생분해도가 감소하였으므로, $\mathrm{NF}$ 를 이용한 장기운전은 소화 효율의 저하를 가져올 수 있다. ${ }^{37)}$ 염분의 축적은 미생물의 활성을 방해하는 요소로써 특히 $2 \%$ 이상의 농도에서 $\mathrm{COD}$ 제거효율과 바이오가스 발생량 이 급격히 줄어든다. ${ }^{38)} \mathrm{MF}, \mathrm{UF}$ 는 염분이 전혀 배제되지 않 는 것으로 나타났으나 $\mathrm{NF}$ 의 경우에는 염분 배제율이 $7 \%$ 정도로 염분이 축적될 가능성을 보였다. 결과적으로 물질의 분리 특성은 MF와 UF가 적합하게 나타났지만, 투과 유속 의 감소와 회복을 고려하면 UF가 가장 적합한 것을 알 수 있다.

\subsection{3. 막면 유속에 따른 투과 유속 변화}

$\mathrm{AnMBR}$ 에서 투과 유속 감소의 주요 원인은 막면에 형성 된 케익층과 젤층에 기인하는 것으로 알려져 있다. ${ }^{39)}$ 이는 막 면에 유입수의 흐름을 통해 막 표면에 전단력(Shear force) 을 주어 완화할 수 있으며, 전단력은 표면 유속과 관계가 있다. ${ }^{40)}$ 따라서 막표면의 선속도에 의한 투과 유속의 변화 를 평가하기 위해 ${ }^{41)}$ Stirred cell 내부에 장착된 마그네틱 바 의 회전 속도를 조절하여 막면 유속을 0 (Dead-end), 0.31, $0.94,1.57,2.20 \mathrm{~m} / \mathrm{s}$ 로 모사하였다. NF막은 막면 유속 0 (Dead-end), $0.31,0.47,0.94 \mathrm{~m} / \mathrm{s}$ 에 대하여 조사하였다.

2상 혐기성 소화 장치의 메탄생성조 혐기 소화 슬러지의 막 여과시 막면 유속변화에 따른 각 막의 투과 유속을 Fig. 6에 나타내었다. 막면 유속별 여과 초기 10 분간은 투과 유 속이 급격하게 감소였으며 그 이후 투과 유속이 유지되었다. $\mathrm{MF}$ 막의 투과 유속은 막면 유속 $0.94 \mathrm{~m} / \mathrm{s}$ 이상에서 $2.8 \sim 3.0$ $\mathrm{L} / \mathrm{m}^{2} \cdot \mathrm{h} \cdot \mathrm{bar}$ 로 유사하게 나타나 막면유속 $0.31 \mathrm{~m} / \mathrm{s}$ 에 비해 투과 유속이 증가했다. 이는 막면 유속의 전단력으로 케익 및 젤층 형성을 억제함으로써 투과 유속을 향상시키는 연구 결과에 부합한다. ${ }^{42}$

$\mathrm{UF}$ 막의 유지 투과 유속은 유속 $0.31 \mathrm{~m} / \mathrm{s}$ 이하에서 1.5 $\mathrm{L} / \mathrm{m}^{2} \cdot \mathrm{h} \cdot \mathrm{bar}$ 로 나타났으나 막면 유속이 $0.94,1.57,2.20 \mathrm{~m} / \mathrm{s}$ 로 증가함에 따라 투과 유속도 $3.6,5.9,8.3 \mathrm{~L} / \mathrm{m}^{2} \cdot \mathrm{h} \cdot \mathrm{bar}$ 로 증가하였다. 이는 막 표면의 전단력에 의해 막의 표면에 케 익 및 젤층이 형성되는 것을 방지함으로써 유지 투과 유속

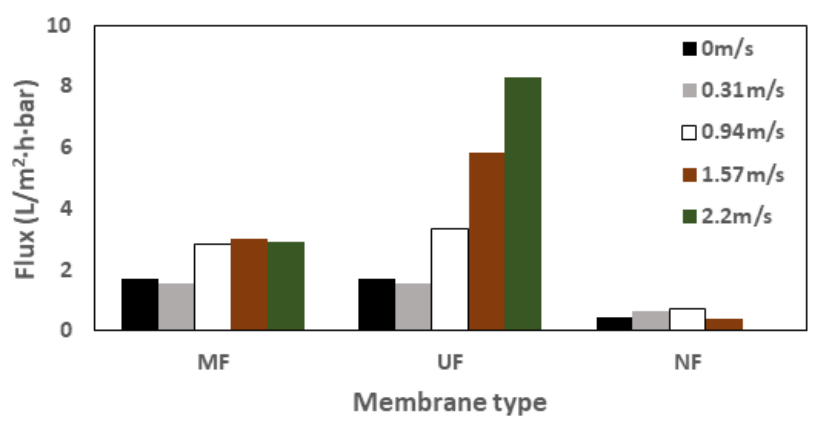

Fig.6. Stable flux variation of the MF, UF and NF membrane at different membrane surface velocity.

이 향상되는 결과를 보여준다. ${ }^{42)}$

$\mathrm{NF}$ 의 경우 초기 투과 유속과 유지 투과 유속의 차이가 거 의 없었고 막면 유속이 0 에서 $0.31,0.94,1.57 \mathrm{~m} / \mathrm{s}$ 로 증가함 에 따라 유지 투과 유속은 $0.45,0.63,0.74,0.37 \mathrm{~L} / \mathrm{m}^{2} \cdot \mathrm{h} \cdot \mathrm{bar}$ 였다. 이상으로부터 NF는 막면유속의 증가보다 고압 및 고 온의 조건에서 투과 유속의 향상이 유리한 것으로 판단된 다. ${ }^{41)}$ 따라서 $\mathrm{NF}$ 는 메탄생성조 내 슬러지의 SRT를 조절하 기 위한 막으로 경제적인 측면에서 부적합하다.

\subsection{UF 막에 의한 십자류 흐름 여과 특성}

막의 공극이 다른 MF, UF, NF 막을 대상으로 투과 유속 의 감소와 회복, 막면 유속에 의한 투과 유속 개선, 막 여과 저항을 비교 및 평가한 결과로부터 UF가 가장 적용가능성 이 높게 나타났다. 그러나 Stirred cell을 이용한 실험결과는 실제 십자류 여과 방식의 모듈과 다른 양상을 나타내는 경 우가 있다. ${ }^{43)}$ 따라서 이전 실험에서 가장 적용 가능성이 높 게 나타난 UF막을 십자류 여과 방식의 평판형 모듈에서 혼 합액을 여과했을 때 투과 유속 변화와 물리적 세척에 의한 회복률을 관찰하고 파울링을 일으키는 물질을 조사하였다.

\subsection{1. 투과 유속의 변화}

$\mathrm{UF}$ 막을 십자류 여과 방식의 평판형 모듈에 장착하여 여과 실험을 진행하였으며, 1 회당 4 시간씩 총 3 회 실시하였다. 1 회 여과 종료 후, 막 표면을 스펀지와 증류수를 이용해 물리 적으로 세척하였다. 여과 시간에 따른 $1,2,3$ 회의 투과 유속 변화를 1분 간격으로 측정하였으며 그 결과를 Fig.7에 나타 내었다. $1,2,3$ 회의 평균 투과 유속은 각각 $19.86,18.54$, $17.21 \mathrm{~L} / \mathrm{m}^{2} \cdot \mathrm{h} \cdot \mathrm{bar}$ 로 막면 유속이 $0.24 \mathrm{~m} / \mathrm{s}$ 로 낮음에도 불구 하고 Stirred cell에서 모사한 막면유속 $2.2 \mathrm{~m} / \mathrm{s}$ 에서 나타난 투과 유속 $8.3 \mathrm{~L} / \mathrm{m}^{2} \cdot \mathrm{h} \cdot \mathrm{bar}$ 에 비해 2 배 이상 높게 나타났다. 이는 타 연구에서 Polyethersulfone으로 만들어진 분획분자 량(MWCO: molecular weight cut off) $50 \mathrm{kDa}$ 의 막을 장착한 Stirred cell과 십자류 여과 방식의 모듈을 이용하여 같은 시 료를 정압여과했을 때 투과 유속이 각각 80 과 $100 \mathrm{~L} / \mathrm{m}^{2} \cdot \mathrm{h}$ 로, 실제 모듈의 투과 유속이 우수한 것과 유사한 결과이며, 


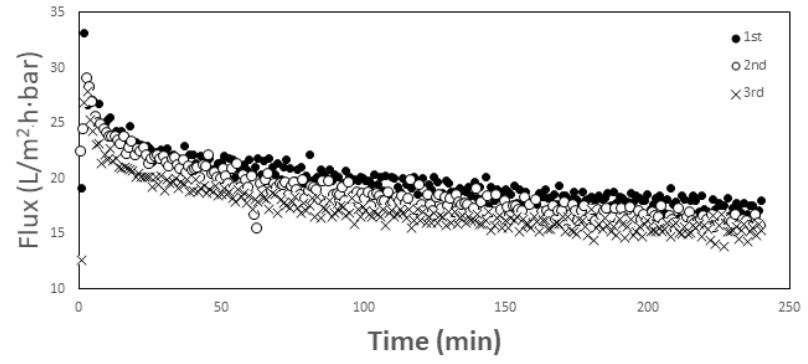

Fig. 7. Variation of flux with time on UF membrane.

막 공극이 클수록 Stirred cell과 십자류 흐름 여과 방식 모듈 의 투과 유속 차이가 상이하다고 판단된다. ${ }^{43} 2,3$ 회차의 투 과 유속 회복률은 각각 $93,87 \%$ 였다. 케익 및 젤층의 제거로 90\% 이상의 투과 유속을 회복할 수 있으므로 주요 파울링 메커니즘이 케익 및 젤층 형성임을 알 수 있다. 이는 Charfi 가 UF막을 이용한 막 결합형 혐기성 소화에서 막의 재질과 모듈의 형태와 관계없이 투과 유속 감소에 가장 지대한 영향 을 미치는 파울링 메커니즘은 케익 및 젤층 형성임을 밝힌 바 있다. ${ }^{39)}$ 하지만 Pore blocking과 Intermediate blocking과 같은 메커니즘에 의해 $6 \sim 7 \%$ 의 투과 유속이 지속적으로 감 소하였다. 이러한 파울링은 역세척 혹은 화학적 세척에 의 해 회복될 수 있다. ${ }^{44}$ Zayen et al.은 매립지 침출수를 UF막 이 결합된 AnMBR로 처리하였을 때 투과유속이 초기 8 $\mathrm{L} / \mathrm{m}^{2} \cdot \mathrm{h}$ 에서 2 3일간은 큰 폭으로 감소하여 $3 \mathrm{~L} / \mathrm{m}^{2} \cdot \mathrm{h}$ 에 도 달했다. ${ }^{45)}$ Saddoud et al.은 도시 폐수를 UF막이 결합된 $\mathrm{AnMBR}$ 로 처리하였으며 투과 유속이 초기 $13 \mathrm{~L} / \mathrm{m}^{2} \cdot \mathrm{h}$ 에서 30 일간 지속적으로 감소하여 약 $9 \mathrm{~L} / \mathrm{m}^{2} \cdot \mathrm{h}$ 에서 유지되었다. ${ }^{46)}$ 이 결과를 미루어 보아 UF막이 결합된 $\mathrm{AnMBR}$ 의 장기운전 에서 투과 유속은 30 70\% 정도 지속적인 감소를 보일 것으 로 예측된다.

\subsection{2. 투과수의 성상 분석}

$\mathrm{UF}$ 막의 물질 배제 특성을 파악하기 위해 여과에 사용된 유입수와 농축수(Concentrate), 투과수(Permeate)의 다양한 수 질을 분석 및 비교하였다. $\mathrm{COD}, \mathrm{SS}, \mathrm{pH}$, 염도의 분석 결과를 Table 6에, VS와 EPS (Extracellular polymeric substances)의 함량, 추출된 EPS 중 탄수화물과 단백질의 분석 결과를 Table 7에 나타내었다.

유입수와 농축수, 투과수의 TCOD는 각각 $21 \mathrm{~g} / \mathrm{L}, 23 \mathrm{~g} / \mathrm{L}$, $1.3 \mathrm{~g} / \mathrm{L}$ 이며, $\mathrm{SS}$ 는 $25.5 \mathrm{~g} / \mathrm{L}, 27.9 \mathrm{~g} / \mathrm{L}, 0 \mathrm{~g} / \mathrm{L}$ 였다. 여과에 의 한 유입수의 $\mathrm{TCOD}$ 와 $\mathrm{SS}$ 의 증가율은 각각 $10 \%$ 와 $9 \%$ 로 나 타났다. TCOD의 상승은 미생물을 포함하는 $\mathrm{SS}$ 농축의 결 과로 볼 수 있다. 유입수와 농축수, 투과수의 염도는 $0.93 \%$, $0.92 \%, 0.90 \%$ 로, 막 여과 이후 염분의 축척이 심화되지 않 을 것으로 판단된다. ${ }^{47)}$

농축수의 $\mathrm{VS}$ 농도가 유입수에 비해 약 $14 \%$ 증가할 때, $\mathrm{EPS}$ 함량은 약 $4 \%$ 증가하였으며, 미생물의 농축도가 유기
Table 6. The characteristics of feed, concentrate and permeate (COD, SS, pH and salinity).

\begin{tabular}{cccc} 
Characteristics & Feed & Concentrate & Permeate \\
$\begin{array}{c}\text { COD } \\
(\mathrm{g} / \mathrm{L})\end{array}$ & 21 & 23 & 1.3 \\
$\mathrm{SS}$ & 25.5 & 27.9 & - \\
$(\mathrm{g} / \mathrm{L})$ & 8.0 & 8.2 & 8.4 \\
$\mathrm{pH}$ & 0.93 & 0.92 & 0.90 \\
$\begin{array}{c}\text { Salinity } \\
(\%)\end{array}$ & & \\
\hline
\end{tabular}

Table 7. The characteristics of feed, concentrate and permeate (VS, EPS content and composition as carbohydrate and protein).

\begin{tabular}{cccc}
\hline Characteristics & Feed & Concentrate & Permeate \\
$\begin{array}{c}\text { VS of feed } \\
(\mathrm{g} / \mathrm{L})\end{array}$ & 16.0 & 18.2 & 2.55 \\
$\begin{array}{c}\text { VS of EPS } \\
(\mathrm{g} / \mathrm{L})\end{array}$ & 4.25 & 5.60 & - \\
$\begin{array}{c}\text { Content of EPS } \\
\text { (mg-EPS/g-VS) } \\
\begin{array}{c}\text { Carbohydrate } \\
(\mathrm{mg} / \mathrm{L})\end{array}\end{array}$ & 266 & 308 & - \\
$\begin{array}{c}\text { Protein } \\
(\mathrm{mg} / \mathrm{L})\end{array}$ & 240 & 670 & 33 \\
\hline
\end{tabular}

물보다 높게 나타났으므로 혐기성 소화 슬러지의 SRT를 안 정적으로 증가시켜 소화 효율이 향상될 수 있다. 또한, SRT 를 증가시키면 EPS에 의한 막 여과 저항이 감소되는 효과 를 기대할 수 있다. ${ }^{48)}$ 일반적으로 혐기성 소화에서 단백질 의 농도는 탄수화물에 비해 5 배 정도 높게 나타나며, 막 여 과에서 단백질의 투과량이 높게 나타나 여과 후 단백질/탄 수화물의 비가 5 에서 4 로 감소한 것을 알 수 있다. ${ }^{48)}$

\subsection{3. 막 오염 물질 분석}

여과 전과 후, 그리고 물리적 세척 후 막의 표면을 관찰하 기 위해 Scanning Electron Microscopy (SEM)으로 촬영하였 다. 동시에 Energy Dispersive Microscopy (EDS)를 이용하 여 막 오염 물질의 구성 원소를 확인하였다. SEM 이미지와 EDS 결과를 Fig.8에 나타내었다.

여과 전 막의 표면은 $\mathrm{EDS}$ 결과에 의해 $\mathrm{PES}$ 의 구성원소인 $\mathrm{C}, \mathrm{O}, \mathrm{S}$ 만이 관찰되었다(Fig.8(a)). 여과 후 막의 표면은 케 익층과 다양한 입자상 물질이 끼어있는 상태를 확인할 수 있었으며, 케익층이 형성되어 $\mathrm{C}$ 와 $\mathrm{S}$ 의 비율은 감소하고

(Fig. 8(b)) $\mathrm{N}, \mathrm{Mg}, \mathrm{P}, \mathrm{Na}, \mathrm{Cl}$ 등 다양한 원소가 관찰되었다. 그 중 $\mathrm{N}, \mathrm{Mg}, \mathrm{P}$ 는 Struvite를 구성하는 원소로써 막 결합형 혐기성 소화에서 주로 관찰되는 막오염물질이다. ${ }^{43,49)}$ 그리 고 음식물쓰레기의 높은 염분이 다양한 입자와 엉겨 붙어 $\mathrm{Na}$ 와 $\mathrm{Cl}$ 이 관찰되었고, 전체 혐기성 소화 공정에서 가용화 


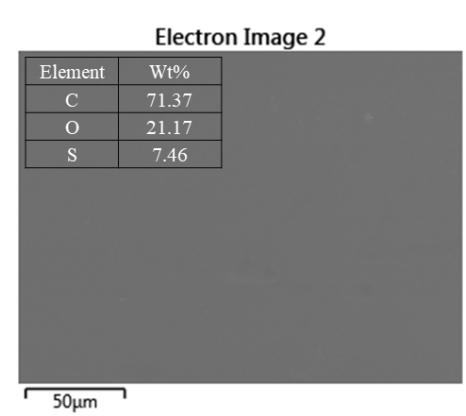

(a)

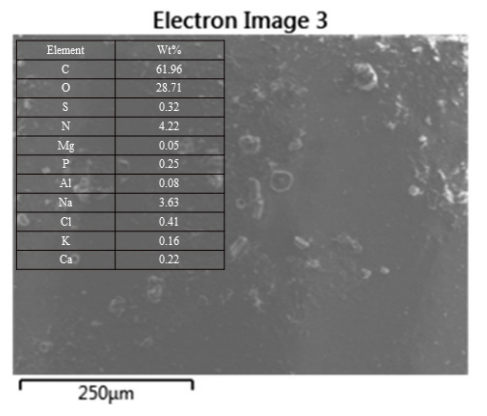

(b)

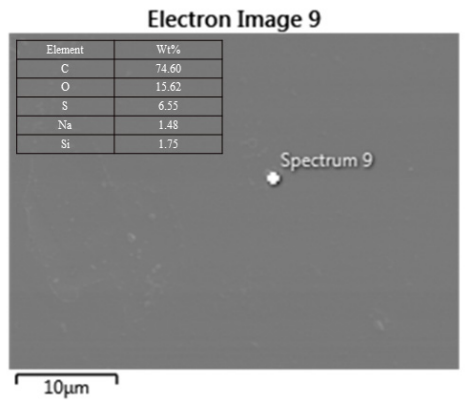

(c)

Fig. 8. SEM image and EDS result of membrane surface (a) virgin, (b) fouled (c) physically washed membrane.

를 위한 $\mathrm{NaOH}$ 주입이 있으므로 $\mathrm{Na}$ 가 $3.63 \%$ 로 $\mathrm{Cl}$ 보다 높 게 관찰되었다. 그 외 $\mathrm{Al}, \mathrm{K}, \mathrm{Ca}$ 와 같은 미네랄 성분이 관찰 되었다. 물리적 세척 후 막의 표면은 여과 전과 유사한 수준 으로 케익층이 제거되었으나 $\mathrm{C}$ 원소를 포함하는 유기물과 소량의 $\mathrm{Na}$ 이온과 $\mathrm{Si}$ 이온이 제거되지 않고 남아있는 것으로 사료된다.

막 오염 물질의 원소 결합을 확인하여 주요 물질을 확인 하고자 여과 전, 후 그리고 물리적 세척 후의 막을 FTIR을 이용하여 분석하였으며 그 결과를 Fig. 9에 나타내었다.

여과 전 막의 FTIR peak는 1661, 1577, 1467, 1412, 1322, $1298,1242,1151$ 그리고 $1106 \mathrm{~cm}^{-1}$ 의 파장에서 나타났다. Zhu 등은 1580 (benzene ring), 1488 (C-C bond), 1244 (aromatic ether) 그리고 1106 (C-O bond) $\mathrm{cm}^{-1}$ 이 polyethersulfone (PES) 막의 고유 피크라고 주장했다. ${ }^{50)}$ 그리고 $\mathrm{Qu}$ 등의 연구에 의 하면 1324 과 $1239 \mathrm{~cm}^{-1}$ 이 C-O-C stretch, 1151 과 $1105 \mathrm{~cm}^{-1}$ 이 $\mathrm{S}=\mathrm{O}$ stretch를 의미하는 피크라고 보고했다. ${ }^{51)}$

여과 후 막에서는 $2916,2849,1632,1574,1539,1469$, 1412,1235 그리고 $1049 \mathrm{~cm}^{-1}$ 의 파장대의 흡수가 일어나 여 과 전 막과는 다른 피크를 나타내었다. 2916 및 $2849 \mathrm{~cm}^{-1}$ 은 알칸 및 지방족 메틸렌 결합의 C-H stretch이다. ${ }^{24,51)}$ 1632 와 $1574,1539 \mathrm{~cm}^{-1}$ 의 피크는 amide 1 과 2 와 같은 단백 질의 분해과정에서 생기는 단백질을 의미한다. ${ }^{51,52)} 1469$ 및 $1412 \mathrm{~cm}^{-1}$ 은 탄산염 $\left(\mathrm{CaCO}_{3}\right)$ 과 같은 무기성 물질을 의미한 다. ${ }^{53,54)}$ 탄산염의 존재는 $\mathrm{EDS}$ 분석 결과에서도 유추할 수 있다. $1049 \mathrm{~cm}^{-1}$ 의 넓은 스펙트럼은 다당류 또는 다당류 유 사 물질을 나타낸다. ${ }^{24,51)}$ SEM-EDS와 FTIR의 결과를 통해 케익층은 주로 탄수화물과 단백질의 부산물, 미생물을 포함 하는 유기 성분으로 구성되어 있으며 $\mathrm{Na}, \mathrm{Cl}, \mathrm{CaCO}_{3}$ 와 같 은 무기 성분이 소량으로 구성되어 있음을 알 수 있다. 물리 적 세척 후 막의 표면에도 주로 $\mathrm{C}$ 원소를 포함하는 유기 성 분과 $\mathrm{Na}, \mathrm{Si}$ 이온이 잔류해 투과유속을 감소시킨 것으로 사 료되며 이는 화학적 세척으로 회복할 수 있다. ${ }^{55)}$

파울링을 일으키는 물질의 분자량을 분석하기 위해 유입 수, 농축수, 투과수 그리고 케익 및 젤층(Cake layer)의 분자 량 분포를 관찰하였으며 결과를 Fig. 10과 Table 8에 나타내

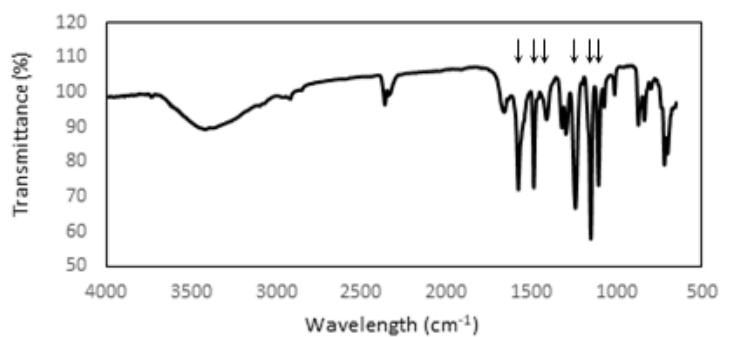

(a)

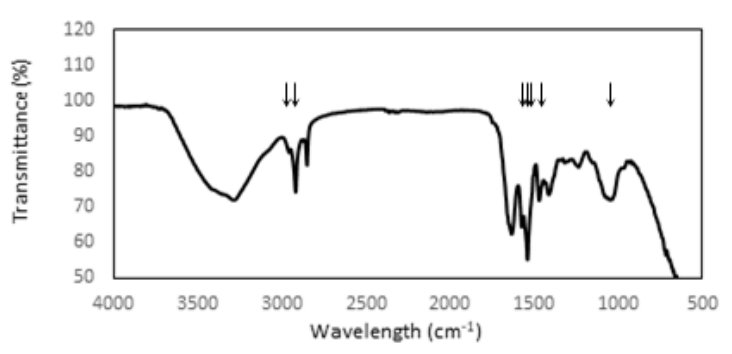

(b)

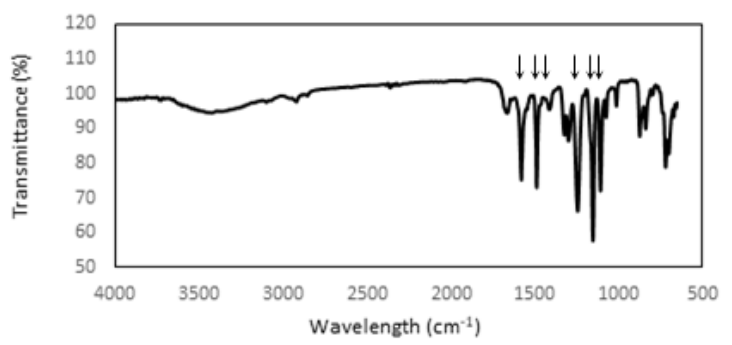

(c)

Fig. 9. FTIR spectrum of membrane surface (a) virgin (b) fouled (c) physically washed membrane.

었다.

Feed에 비해 농축수의 분자량 분포가 $0.5 \sim 1 \mathrm{kDa}$ 에서 $6 \%$ 증가하였고 0.5 이하와 1 5 $\mathrm{kDa}$ 의 물질은 유사하게 나타났으며 나머지는 감소하였다. 한편 $5 \sim 10 \mathrm{kDa}$ 의 물질 은 $2 \%$ 감소하였으나 투과수에서는 거의 나타나지 않아 대 부분 케익층에 쌓이는 것으로 보인다. $10 \sim 15 \mathrm{kDa}$ 도 마찬 가지로 Feed에서 $1 \%$ 인데 반해 농축수와 투과수에서 나타 나지 않아 케익 및 젤층에 의해 배제되었음을 알 수 있다. 


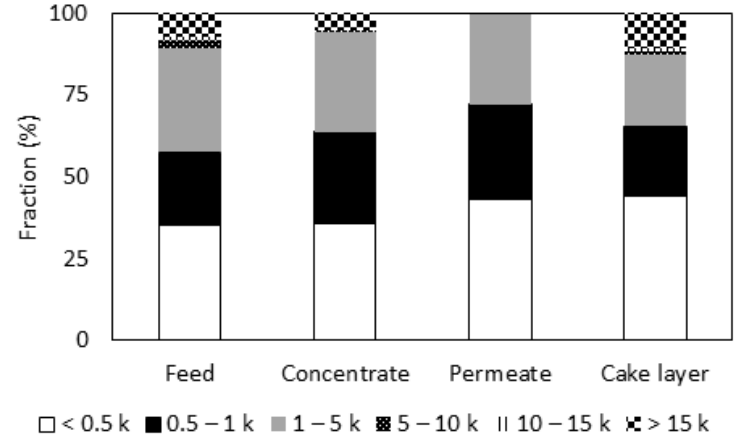

Fig. 10. Molecular weight distribution of feed, concentrate, permeate and cake layer.

농축수에서 $15 \mathrm{kDa}$ 를 초과하는 물질은 Feed의 $7.24 \%$ 에서 $5.33 \%$ 로 감소한 반면 케익층에서 $10.93 \%$ 로 분율이 높아졌 다. 결과적으로 $5 \mathrm{kDa}$ 이상의 물질은 완전히 UF막에 의해 완전히 배제되어 투과수에서 관찰되지 않지만, 농축수보다 케익층에서 높은 분율로 존재하고 있어 막오염에 상당한 영향을 미치는 것으로 판단되며 물리적 세척 후 UF막에 잔 류해 투과 유속을 감소시키는 물질에 대한 연구는 추가로 필요하다.

\section{4. 결론}

본 연구의 목적은 음식물쓰레기를 처리하는 2 상 중온 혐 기성 소화 공정에 막의 적용 가능성을 여과 특성 및 오염 거동의 분석을 통해 평가하였으며 다음과 같은 결론을 도출 하였다.

1) 2 상 중온 혐기성 소화 슬러지의 고형물질은 $25.5 \mathrm{~g} / \mathrm{L}$ (SS), $29.4 \mathrm{~g} / \mathrm{L}$ (TS)로 고농도이며 입도는 주로 $0.5 \sim 700 \mu \mathrm{m}$ 의 범위로 존재하였다. 이를 원심분리 $(5,000 \mathrm{rpm}, 30 \mathrm{~min})$ 할 경우 $12 \mu \mathrm{m}$ 이상의 입자의 제거가 용이하였으나 메탄생 성조의 SRT 조절에는 적합하지 않은 것으로 나타났다.

2) UF막이 MF막과 NF막에 비해 투과 유속 변화와 회복 률, 막 여과 저항을 고려했을 때 가장 적합하였고 막면 유속의 증가에 따라 투과 유속이 뚜렷하게 향상되었다.

3) UF막을 이용한 십자류 여과 방식의 평판형 모듈의 여 과실험에서 투과 유속은 1 회당 4 시간씩 총 3 회 여과에 서 평균 $18 \mathrm{~L} / \mathrm{m}^{2} \cdot \mathrm{h} \cdot \mathrm{bar}$ 로 유지되었다. 투과 유속 감소 에 주된 영향을 미치는 케익층은 물리적 세척에 의해 충분히 제거되어 1,2 회에서 여과에서 각각 $93,85 \%$ 의 투과 유속 회복률을 보여 유지세정에 의해 운전기간을 연장할 수 있다.

4) 물리적 세척 이후 회복되지 않은 투과 유속은 막 면에 잔류하는 탄수화물과 단백질의 분해 산물 등의 유기 성분이 주를 이루었고 소량의 무기 성분(염분, Struvite) 이 존재하였다.
Table 8. Fraction of molecular weight of feed, concentrate, permeate and cake layer.

\begin{tabular}{ccccc} 
Group & Feed & Concentrate Permeate & Cake layer \\
\cline { 2 - 5 } & \multicolumn{4}{c}{$(\%)$} \\
$0.5 k$ & 35.38 & 35.68 & 42.98 & 43.95 \\
$0.5-1 k$ & 22.06 & 28.05 & 29.15 & 21.59 \\
$1-5 k$ & 31.86 & 30.39 & 27.76 & 21.78 \\
$5-10 k$ & 2.42 & 0.55 & 0.12 & 1.11 \\
$10-15 k$ & 1.04 & 0 & 0 & 0.64 \\
$>15 k$ & 7.24 & 5.33 & 0 & 10.93 \\
\hline
\end{tabular}

\section{Acknowledgement}

이 논문은 2019 2020년도 창원대학교 자율연구과제 연구비 지원으로 수행된 연구결과임.

\section{References}

1. A. Moujanni, I. Qarraey, A. Ouatmane, Anaerobic codigestion of urban solid waste fresh leachate and domestic wastewaters: Biogas production potential and kinetic, Environ. Eng. Res., 24(1), 38-44(2018).

2. J. Rodriguez-Iglesias, L. Castrillon, E. Maranon, H. Sastre, Solid-state anaerobic digestion of unsorted municipal solid waste in a pilot-plant scale digester, Bioresour. Technol., 63(1), 29-35(1998).

3. S. Sawayama, S. Inoue, K. Tsukahara, T. Yagishita, T. Minowa, T. Ogi, Anaerobic treatment of liquidized organic wastes, Renew. Energy, 16(1-4), 1094-1097(1999).

4. F. Shen, H. Yuan, Y. Pang, S. Chen, B. Zhu, D. Zou, Y. Liu, J. Ma, L. Yu, X. Li, Performances of anaerobic co-digestion of fruit\&vegetable waste (FVW) and food waste (FW): Single-phase vs. two-phase, Bioresour. Technol., 144, 80-85(2013).

5. F. A. Tassew, W. H. Bergland, C. Dinamarca, R. Bakke, Influences of temperature and substrate particle content on granular sludge bed anaerobic digestion, Appl. Sci., 10(1), 136(2020).

6. S. Sarker, J. J. Lamb, D. R. Hjelme, K. M. Lien, A review of the role of critical parameters in the design and operation of biogas production plants, Appl. Sci., 9(9), 1915(2019).

7. E. A. Salminen, J. A. Rintala, Semi-continuous anaerobic digestion of solid poultry slaughterhouse waste: Effect of hydraulic retention time and loading, Water Res., 36(13), 3175-3182(2002).

8. N. Nagao, N. Tajima, M. Kawai, C. Niwa, N. Kurosawa, T. Matsuyama, F. Md. Yusoff, T. Toda, Maximum organic loading rate for the single-stage wet anaerobic digestion of food waste, Bioresour. Technol., 118, 210-218(2012).

9. K. Boe, Online monitoring and control of the biogas process, doctoral thesis, Technical University of Denmark, Copenhagen, Denmark(2006).

10. Y. M. Amha, M. Corbett, A. L. Smith, Two-phase improves 
performance of anaerobic membrane bioreactor treatment of food waste at high organic loading rates, Environ. Sci. Technol., 53(16), 9572-9583(2019)

11. L. Appels, J. Baeyens, J. Degreve, R. Dewil, Principles and potential of the anaerobic digestion of waste-activated sludge, Prog. Energ. Combust., 34(6), 755-781(2008).

12. X. Mei, Z. Wang, Y. Miao, Z. Wu, A pilot-scale anaerobic membrane bioreactor under short hydraulic retention time for municipal wastewater treatment: performance and microbial community identification, J. Water Reuse Desal., 8(1), 58-67(2018).

13. M. Maaz, M. Yasin, M. Aslam, G. Kumar, A. E. Atabani, M. Idrees, F. Anjum, F. Jamil, R. Ahmad, A. L. Khan, G. Lesage, M. Heran, J. Kim, Anaerobic membrane bioreactors for wastewater treatment: Novel configurations, fouling control and energy considerations, Bioresour. Technol., 283, 358-372(2019).

14. M. D. Seib, K. J. Berg, D. H. Zitomer, Low energy anaerobic membrane bioreactor for municipal wastewater treatment, J. Membr. Sci., 514, 450-457(2016).

15. M. A. Dixon, T. R. Abbas, M. H. Al-Furaiji, R. H. Abed-Ali, Membrane bioreactor with external side-stream membranes and high cross flow velocity to treat municipal wastewater, Engineering and Technology Journal, 38(1A), $1-8(2020)$.

16. D. C. Stuckey, Recent developments in anaerobic membrane reactors, Bioresour. Technol., 122, 137-148(2012).

17. T. Srisukphun, C. Chiemchaisri, W. Chiemchaisri, M. Thanuttamavong, Fouling and cleaning of reverse osmosis membrane applied to membrane bioreactor effluent treating textile wastewater, Environ. Eng. Res., 21(1), 45-51(2016).

18. J. Kim, F. A. DiGiano, R. D. Reardon, Autopsy of high-pressure membranes to compare effectiveness of MF and UF pretreatment in water reclamation, Water Res., 42(3), 697-706(2008).

19. J.-B. Castaing, A. Massé, M. Pontié, V. Séchet, J. Haure, P. Jaouen, Investigating submerged ultrafiltration (UF) and microfiltration (MF) membranes for seawater pre-treatment dedicated to total removal of undesirable micro-algae, Desalination, 253(1-3), 71-77(2010).

20. X. Sun, C. Wang, Y. Tong, W. Wang, J. Wei, A comparative study of microfiltration and ultrafiltration for algae harvesting, Algal Res., 2(4), 437-444(2013).

21. L. Domínguez, V. Cases, C. Birek, M. Rodríguez, D. Prats, Influence of organic loading rate on the performance of ultrafiltration and microfiltration membrane bioreactors at high sludge retention time, Chem. Eng. J., 181-182, 132-143(2012).

22. S. Zulaikha, W. J. Lau, A. F. Ismail, J. Jaafar, Treatment of restaurant wastewater using ultrafiltration and nanofiltration membranes, J. Water Process Eng., 2, 58-62(2014).

23. R. J. LaRue, A. S. Kazemi, D. R. Latulippe, Microscale stirred-cell filtration for high-throughput evaluation of separation performance, Biochem. Eng. J., 130, 34-38(2018).

24. F. Meng, H. Zhang, F. Yang, L. Liu, Characterization of cake layer in submerged membrane bioreactor, Environ. Sci. Technol., 41(11), 4065-4070(2007).

25. E. Lee, H. Kim, L. T. T. Giang, J. Bae, Y. Bae, J. Won, J. Lee, S. Park, Y. Cho, Treatment of garbage leachate with two-phase anaerobic digestion coupled with ultra filtration, J. Korean Soc. Environ. Eng., 31(11), 997-1006(2009).

26. Z. Wang, Z. Wu, G. Yu, J. Liu, Z. Zhou, Relationship between sludge characteristics and membrane flux determination in submerged membrane bioreactors, J. Membr. Sci., 284(1-2), 87-94(2006).

27. M. Dubois, K. A. Gilles, J. K. Hamilton, P. A. Rebers, F. Smith, Colorimetric method for determination of sugars and related substances, Anal. Chem., 28(3), 350-356(1956).

28. B. Frølund, R. Palmgren, K. Keiding, P. H. Nielsen, Extraction of extracellular polymers from activated sludge using a cation exchange resin, Water Res., 30(8), 1749-1758(1996).

29. Z. He, D. Xia, Y. Huang, X. Tan, C. He, L. Hu, H. He, J. Zeng, W. Xu, D. Shu, 3D $\mathrm{MnO}_{2}$ hollow microspheres ozone-catalysis coupled with flat-plate membrane filtration for continuous removal of organic pollutants: Efficient heterogeneous catalytic system and membrane fouling control, J. Hazard. Mater., 344, 1198-1208(2018).

30. Y. Kim, H. Jang, H. Lee, O\&M experience of food waste to biogas energy plant according to korean food waste characteristics, Korean Society of Civil Engineers Magazine, 66(11), 70-75(2018).

31. J.-I. Horiuchi, T. Shimizu, K. Tada, T. Kanno, M. Kobayashi, Selective production of organic acids in anaerobic acid reactor by $\mathrm{pH}$ control, Bioresour. Technol., 82(3), 209-213(2002).

32. H. Lee, H. Jang, Y. O. Kim, Evaluation of a long-term operation for anaerobic digestion coupled with UF membrane in food waste biogas plant, in Autumn proceedings of the Membrane Society of Korea, The Membrane Society of Korea, Busan, pp. 59(2017).

33. X.-M. Wang, X.-Y. Li, X. Huang, Membrane fouling in a submerged membrane bioreactor (SMBR): Characterisation of the sludge cake and its high filtration resistance, Sep. Purif. Technol., 52(3), 439-445(2007).

34. J.-H. Choi, K. Fukushi, K. Yamamoto, A study on the removal of organic acids from wastewaters using nanofiltration membranes, Sep. Purif. Technol., 59(1), 17-25(2008).

35. A. Munir, Dead end membrane filtration, Laboratory Feasibility Studies in Environmental Engineering, PID A, 37589962(2006).

36. M. Kim, Efficiency Enhancement and Application Assessment of Two-phase Thermophilic Anaerobic Digestion with Membrane, doctoral thesis, University of Seoul, Seoul, Korea(2012).

37. J. Joo, Analysis of Treatment Efficiency and Flux Prediction of UF Membrane Process in Anaerobic digestion, doctoral thesis, University of Seoul, Seoul, Korea(2012).

38. J. W. Park, M. C. Kim, J. H. Song, J. H. Lim, A study on the characteristics of food wastes according to generation source and season, J. Korea Soc. Waste Manag., 18(7), 
595-603(2001).

39. A. Charfi, N. B. Amar, J. Harmand, Analysis of fouling mechanisms in anaerobic membrane bioreactors, Water Res., 46(8), 2637-2650(2012).

40. T. Horie, S. Shiota, T. Akagi, N. Ohmura, S. Wang, V. Eze, A. Harvey, Y. Hirata, Intensification of hollow fiber membrane cross-flow filtration by the combination of helical baffle and oscillatory flow, J. Membr. Sci., 554, 134-139(2018).

41. H. Saitúa, M. Campderrós, S. Cerutti, A. P. Padilla, Effect of operating conditions in removal of arsenic from water by nanofiltration membrane, Desalination, 172(2), 173-180(2005).

42. K.-J. Hwang, S.-J. Lin, Filtration flux - shear stress - cake mass relationships in microalgae rotating-disk dynamic microfiltration, Chem. Eng. J., 244, 429-437(2014).

43. N. O. Becht, D. J. Malik, E. Tarleton, Evaluation and comparison of protein ultrafiltration test results: Dead-end stirred cell compared with a cross-flow system, Sep. Purif. Technol., 62(1), 228-239(2008).

44. M. Kazemimoghadam, T. Mohammadi, Chemical cleaning of ultrafiltration membranes in the milk industry, Desalination, 204(1-3), 213-218(2007).

45. A. Zayen, S. Mnif, F. Aloui, F. Fki, S. Loukil, M. Bouaziz, S. Sayadi, Anaerobic membrane bioreactor for the treatment of leachates from jebel chakir discharge in tunisia, J. Hazard. Mater., 177(1-3), 918-923(2010).

46. A. Saddoud, M. Ellouze, A. Dhouib, S. Sayadi, Anaerobic membrane bioreactor treatment of domestic wastewater in tunisia, Desalination, 207(1-3), 205-215(2007).

47. J. Zhang, Y. Zhang, X. Quan, Electricity assisted anaerobic treatment of salinity wastewater and its effects on microbial communities, Water Res., 46(11), 3535-3543(2012).

48. P. Grelier, S. Rosenberger, A. Tazi-Pain, Influence of sludge retention time on membrane bioreactor hydraulic performance, Desalination, 192(1-3), 10-17(2006).

49. I.-J. Kang, S.-H. Yoon, C.-H. Lee, Comparison of the filtration characteristics of organic and inorganic membranes in a membrane-coupled anaerobic bioreactor, Water Res., 36(7), 1803-1813(2002).

50. S. Zhu, M. Shi, S. Zhao, Z. Wang, J. Wang, S. Wang, Preparation and characterization of a polyethersulfone/polyaniline nanocomposite membrane for ultrafiltration and as a substrate for a gas separation membrane, RSC Advances, 5(34), 27211-27223(2015).

51. P. Qu, H. Tang, Y. Gao, L. Zhang, S. Wang, Polyethersulfone composite membrane blended with cellulose fibrils, BioResources, 5(4), 2323-2336(2010).

52. E. Ayala-Bribiesca, G. Pourcelly, L. Bazinet, Nature identification and morphology characterization of cation-exchange membrane fouling during conventional electrodialysis, J. Colloid Interface Sci., 300(2), 663-672(2006).

53. M. Lee, J. Kim, Membrane autopsy to investigate $\mathrm{CaCO}_{3}$ scale formation in pilot scale, submerged membrane bioreactor treating calcium rich wastewater, J. Chem. Technol. Biotechnol., 84(9), 1397-1404(2009).

54. R. L. Barbour, R. J. Jakobsen, W. Henry, K. Knapp, Inorganic compound speciation by fourier transform infrared (FTIR), in Proceedings of 1981 International Conference on Fourier Transform Infrared Spectroscopy, International Society for Optics and Photonics, Columbia, USA, pp. 245-250(1981).

55. R. Liikanen, J. Yli-Kuivila, R. Laukkanen, Efficiency of various chemical cleanings for nanofiltration membrane fouled by conventionally-treated surface water, J. Membr. Sci., 195(2), 265-276(2002).

\section{Authors}

\section{Min-Ju Park}

Department of Environmental and Chemical Engineering, Eco-friendly Offshore Plant FEED Engineering Course, Changwon National University, Ph.D. Candidate, ORCID(1) 0000-0003-0034-7680

\section{Gyu-Tae Seo}

School of Civil, Environmental and Chemical Engineering, Changwon National University, Professor, ORCiD(D) 0000-00024424-7844 